\title{
Pengaruh Motivasi, Kreativitas, Inovasi dan Modal Usaha terhadap Minat Berwirausaha
}

\author{
Nanda Tri Wardani*, Retno Mustika Dewi \\ Fakultas Ekonomi dan Bisnis, Universitas Negeri Surabaya, Surabaya, Indonesia \\ *nanda.17080554037@mhs.unesa.ac.id
}

\begin{abstract}
Entrepreneurial interest is believed to be the most powerful solution in solving labor problems among students. However, the phenomenon that occurs in UNESA Economic Education Study Program students is still not optimal in interpreting this solution. This study identifies the influence of motivation, creativity, innovation and venture capital on interest in entrepreneurship. The data analysis technique used multiple linear regression and descriptive statistics. A sample of 60 students used purposive sampling technique. The results of the study show that motivation, creativity and venture capital partially significant effect on entrepreneurial interest. Only innovation shows that there is no significant influence on entrepreneurial interest.
\end{abstract}

\section{Keywords: Creativity, Entrepreneurial Interest, Innovation, Motivation, Venture Capital}

\section{PENDAHULUAN}

Kewirausahaan merupakan solusi terbaik dalam kasus dimana seorang individu yang berpendidikan tidak dapat menemukan pekerjaan (Neneh, 2014). Kasus tersebut yang menjadi tantangan tersendiri bagi perguruan tinggi sebagai lembaga penghasil lulusan (Wahyu \& Ranto, 2016). Sebagaimana fenomena yang terjadi pada mahasiswa Prodi Pendidikan Ekonomi UNESA. Berdasarkan hasil wawancara yang peneliti lakukan kepada 16 mahasiswa terkait pemilihan karir pekerjaan, didapat hasil sebanyak 11 mahasiswa menyatakan bahwa untuk sekarang ini mereka lebih memilih untuk menjadi pencari kerja daripada pencipta lapangan kerja. Sembilan mahasiswa diantaranya menyatakan bahwa mereka ingin bekerja sebagai pegawai perusahaan swasta maupun BUMN. Padahal menurut Sihombing dan Sumantri (2014) untuk mendapatkan pekerjaan di perusahaan- perusahaan yang diinginkan oleh kesembilan mahasiswa tersebut merupakan hal yang sangat sulit. Kemudian, 2 mahasiswa diantaranya menyatakan bahwa mereka ingin bekerja sebagai pegawai negeri sipil (PNS). Sedangkan sisanya dari 5 mahasiswa, 1 mahasiswa menyatakan ingin menjadi wirausahawan dan 4 mahasiswa diantaranya menyatakan bahwa mereka belum mengetahui akan bekerja apa. Fenomena ini sebagaimana yang dikatakan oleh Herdjiono et al. (2018) dan Prakoso, Kurniawan dan Soesatyo (2019) bahwa banyak sarjana memutuskan bekerja menjadi pegawai perusahaan atau pegawai negeri dan hanya sedikit dari mereka yang berpikir untuk menjadi seorang wirausahawan.

Wirausahawan adalah seseorang yang menjalankan ataupun mendirikan usahanya sendiri dengan tujuan untuk mendapatkan profit (Mintardjo et al., 2020). Menurut Yulianeu dan Harini (2018) peningkatan 
jumlah wirausahawan akan menciptakan ketersediaan lapangan kerja. Hal tersebut sama seperti ungkapan Ranto (2016), dimana dengan menumbuhkan wirausahawan dari kalangan sarjana dapat menambah kuantitas lapangan kerja dan mengurangi pertambahan jumlah pengangguran. Namun, sekarang ini banyak ditemui fenomena sebagaimana yang disampaikan oleh Nurmaliza et al. (2018), dimana tidak semua mahasiswa berminat untuk berwirausaha setelah lulus, sehingga akan berdampak pada meningkatnya angka pengangguran. Berdasarkan BPS (2020) persentase pengangguran menurut pendidikan yang ditamatkan di perguruan tinggi mencapai 5,73\%. Dan angka tersebut merupakan angka yang lebih besar jika dibandingkan dengan tingkat pengangguran di jenjang SD dan SMP yang hanya mencapai $2,64 \%$ dan 5,02\%. Menurut Osakede et al. (2017), obat mujarab dari masalah pengangguran tersebut adalah minat berwirausaha di kalangan muda seperti mahasiswa. Dengan adanya minat berwirausaha maka kemungkinan dimulainya aksi dalam berwirausaha dapat diharapkan. Sebab aksi berwirausaha dapat dimulai jika ada minat terlebih dahulu (Karen Hapuk et al., 2020). Sehingga minat berwirausaha tentu menjadi hal yang perlu untuk terus dikembangkan di kalangan mahasiswa.

Menurut Mahanani dan Sari (2018) minat berwirausaha merupakan keinginan seseorang untuk menjalankan usaha sendiri. Namun, pada literatur lain ada yang mengatakan bahwa minat berwirausaha itu tidak hanya sebatas keinginan untuk menjalankan usaha sendiri. Sebagaimana yang ditegaskan oleh Mat et al. (2015), minat berwirausaha itu tidak hanya sebatas keinginan saja, tetapi keinginan yang disertai dengan adanya pembuktian lanjutan berupa tindakan nyata untuk ikut terlibat dalam kegiatan kewirausahaan. Dalam penelitian Nurmaliza et al. (2018) juga menyatakan bahwa ada 4 indikator dari minat berwirausaha, dan salah satu indikator tersebut adalah keterlibatan dalam kegiatan kewirausahaan.
Berdasarkan hasil wawancara yang peneliti lakukan, belum semua mahasiswa PE (Prodi Pendidikan Ekonomi UNESA) terlibat dalam kegiatan wirausaha. Sebanyak 13 dari 16 mahasiswa menginginkan untuk menjalankan usaha. Sedangkan sisanya sebanyak 3 mahasiswa tidak memiliki keinginan untuk menjalankan usaha. Namun keinginan tersebut rupanya masih keinginan yang belum disertai dengan aksi nyata (praktik) (Larasati, 2020). Karena dari 13 mahasiswa tersebut, hanya 3 mahasiswa yang sekarang sedang menjalankan usaha dan sisanya sebanyak 10 mahasiswa ada yang belum dan sudah berhenti menjalankannya. Padahal menurut Osakede et al. (2017) individu yang sekarang sudah terlibat dalam kegiatan wirausaha jelas memiliki kemungkinan yang lebih tinggi untuk memiliki bisnis di masa depan. Fenomena ini menggerakkan peneliti melakukan pengkajian terkait minat berwirausaha mahasiswa PE (Prodi Pendidikan Ekonomi UNESA).

\section{Motivasi}

Motivasi merupakan suatu dorongan untuk bekerja keras agar memperoleh banyak hal seperti keuntungan, kebebasan pribadi, impian pribadi, dan kemandirian. Sehingga motivasi dapat menimbulkan semangat dalam memberikan respon yang bersifat positif atas kesempatan dalam mendapatkan manfaat yang banyak bagi dirinya sehingga tidak bergantung pada orang lain. Jika motivasi berwirausaha ditingkatkan, maka akan mendorong peningkatan pada minat berwirausaha (Munawar \& Supriatna, 2018).

\section{Kreativitas}

Kreativitas merupakan kemampuan untuk menghadirkan gagasan atau ide dalam memecahkan persoalan saat menghadapi peluang. Dengan adanya kreativitas maka seseorang akan terdorong untuk mencapai target yang ditentukan. Target yang dimaksud dapat berupa target dibidang apapun termasuk dalam bidang kewirausahaan. Sehingga kemampuan berkreativitas dapat digunakan untuk 
melahirkan berbagai ide-ide bisnis yang sesuai dengan peluang yang ada. Apabila kreativitas ditingkatkan, maka akan mendorong peningkatan pada minat berwirausaha (Mahanani \& Sari, 2018).

\section{Inovasi}

Inovasi merupakan kemampuan untuk mengubah peluang menjadi suatu gagasan atau ide-ide yang dapat dijual. Dengan adanya inovasi, keinginan untuk mencapai keberhasilan dalam suatu usaha akan semakin dapat diharapkan. Karena inovasi, seseorang akan mampu menghadapi berbagai ketidakpastian dan ketatnya persaingan di dunia usaha. Jika inovasi ditingkatkan, maka akan mendorong peningkatan pada minat berwirausaha penelitian (Rahmadi, Nur Afif, \& Heryanto, 2016).

\section{Modal Usaha}

Modal usaha dapat diartikan sebagai sejumlah uang yang dapat digunakan untuk membiayai berbagai keperluan usaha. Menurut (Putri et al., 2014), modal usaha ini harus sudah tersedia sebelum seseorang memutuskan untuk melakukan usahanya. Sehingga ketersediaan modal usaha tentu menjadi salah satu faktor penting di dunia bisnis (Tanusi \& Laga., 2020). Maka tidak heran jika modal usaha dikatakan sebagai pemicu minat berwirausaha seorang individu (Alma, 2010). Apabila modal usaha tinggi, maka akan dapat meningkatkan minat berwirausaha (Anggraini, 2017).

Pada riset terdahulu mengungkap beberapa aspek yang mempengaruhi minat berwirausaha. Menurut Gerardo (2017) motivasi instrinsik merupakan faktor terpenting dalam meningkatkan kewirausahaan. Hal tersebut didukung oleh penelitian Kumaran dan Anand (2016), yang menyatakan bahwa tingginya motivasi berwirausaha mahasiswa akan meningkatkan minat berwirausaha di masa depan. Hasil penelitian ini sejalan dengan salah satu alasan mengapa 10 mahasiswa PE (Prodi Pendidikan Ekonomi UNESA) belum optimal mewujudkan keinginannya untuk menjalankan usaha. Sebanyak 2 dari 10 mahasiswa tersebut mengatakan bahwa mereka membutuhkan daya penggerak dari dalam diri yang cukup untuk menjalankan usaha. Fenomena tersebut bertentangan dengan hasil penelitian Dzulfikri, Ahmad dan Kusworo (2017) dimana motivasi tidak mempengaruhi minat berwirausaha.

Selain faktor di atas, kreativitas dan inovasi juga merupakan faktor yang dapat mempengaruhi minat berwirausaha (Mahanani \& Sari, 2018). Suryana (2003) mendefinisikan kreativitas sebagai kemahiran memecahkan masalah dalam menghadapi peluang dengan cara mengembangkan ataupun menemukan ide segar. Sedangkan inovasi dapat didefinisikan sebagai kemampuan untuk membangkitkan, menerima dan menerapkan ide baru, proses, produk atau jasa (Mahanani \& Sari, 2018). Fenomena yang terjadi menunjukkan bahwa aplikasi atau penerapan kreativitas dan inovasi dalam berwirausaha pada mahasiswa PE (Prodi Pendidikan Ekonomi UNESA) masih belum optimal. Hal ini dipertegas oleh argumen 3 mahasiswa yang belum menjalankan usaha. Mereka mengatakan bahwa hingga sekarang mereka belum menemukan inspirasi atau ide bisnis yang tepat. Karena alasan tersebut yang menjadikan mereka hingga sekarang belum maksimal mewujudkan keinginannya dalam menjalankan usaha. Sementara itu, hasil penelitian terdahulu masih menunjukkan hasil penelitian yang pro dan kontra. Hasil penelitian Rahmadi, Nur Afif dan Heryanto (2016) menyatakan "kreativitas dan inovasi berpengaruh terhadap minat berwirausaha". Sedangkan menurut hasil penelitian Noviasari (2018) baik kreativitas ataupun inovasi tidak berdampak signifikan pada minat berwirausaha.

Selain ketiga faktor di atas, modal usaha juga merupakan faktor yang mempengaruhi minat berwirausaha (Anggraini, 2017). Menurut Putri et al. (2014), modal merupakan bagian utama yang harus ada sebelum memulai untuk menjalankan sebuah usaha atau bisnis. Dengan tersedianya modal maka akan dapat 
memicu minat berwirausaha (Alma, 2010). Permasalahan ketersediaan modal ini yang menjadi alasan 12 dari 13 mahasiswa belum maksimal mewujudkan keinginannya untuk menjalankan usaha. Beberapa aspek yang digunakan untuk menjalankan usaha, diantaranya menurut Putri et al. (2014) adalah "tekad, pengalaman, keberanian, pengetahuan, relasi, serta modal uang". Dari beberapa aspek tersebut, rata-rata mahasiswa menyatakan bahwa mereka kesulitan untuk mendapatkan modal uang. Namun menurut Chen et al. (2017) kesulitan terkait modal seperti dalam fenomena ini tidak akan menjadi sebuah masalah dalam memulai untuk menjalankan usaha jika individu tersebut memiliki motivasi yang tinggi.

Tujuan penelitian ini adalah untuk mengidentifikasi pengaruh motivasi, kreativitas, inovasi dan modal usaha terhadap minat berwirausaha baik secara serentak maupun parsial. Adapun kerangka konseptual penelitian ini sebagai berikut:

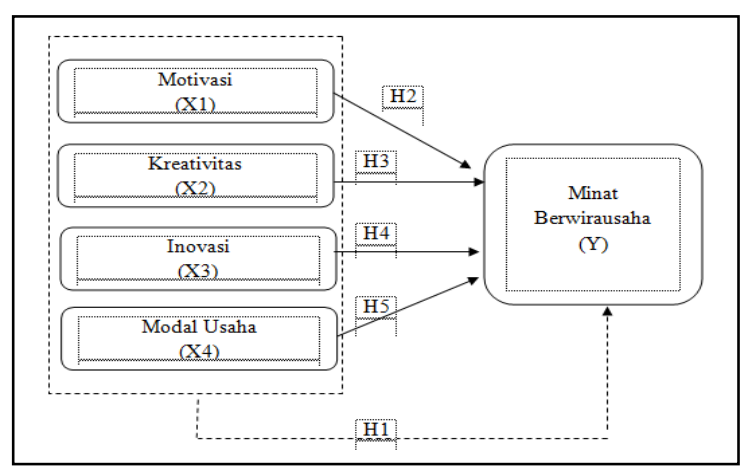

Gambar 1. Kerangka Konseptual

Sumber: dikembangkan oleh peneliti, 2021

\section{Hipotesis}

Berdasarkan uraian latar belakang di atas maka hipotesis penelitian ini adalah:

$\mathrm{H}_{1}$ : Motivasi, kreativitas, inovasi dan modal usaha berpengaruh positif dan signifikan terhadap minat berwirausaha.

$\mathrm{H}_{2}$ : Motivasi berpengaruh positif dan signifikan terhadap minat berwirausaha.

$\mathrm{H}_{3}$ : Kreativitas berpengaruh positif dan signifikan terhadap minat berwirausaha.

$\mathrm{H}_{4}$ : Inovasi berpengaruh positif dan signifikan terhadap minat berwirausaha.

$\mathrm{H}_{5}$ : Modal usaha berpengaruh positif dan signifikan terhadap minat berwirausaha.

\section{METODE}

Jenis penelitian ini adalah penelitian kuantitatif. Populasi penelitian, mahasiswa aktif PE (Prodi Pendidikan Ekonomi UNESA), yaitu terdiri dari angkatan 2017, 2018, dan 2019, yang berjumlah 203 mahasiswa. Sampel ditentukan dengan teknik purposive sampling. Kriteria pokok sampel adalah mahasiswa yang telah menempuh mata kuliah KWU (kewirausahaan). Adapun kriteria tambahan, yaitu: 1) sudah dan/atau belum pernah mengikuti pelatihan KWU, 2) sudah merintis usaha sendiri dan masih berjalan, 3) usaha yang dirintismya sudah berhenti karena faktor tertentu, atau 4) masih sebatas berkeinginan untuk membuka usaha sendiri (Mopangga, 2014). Adapun jumlah anggota sampel ditetapkan sebanyak 60 responden (Roscoe, 1982; Sugiyono, 2016) yang menyatakan bahwa jika penelitian melakukan analisis memakai regresi ganda, maka kuantitas anggota sampelnya paling kecil 10 kali dari total variabel.

Variabel minat berwirausaha (Y) diukur dengan 3 indikator: 1) seberapa kuat upaya seseorang berani mencoba berwirausaha, 2) seberapa banyak upaya yang direncanakan seseorang untuk melakukan aktivitas kewirausahaan (Rahayu \& Laela, 2018), dan 3) karir berwirausaha (Munawar \& Supriatna, 2018). Adapun variabel motivasi berwirausaha (X1) diukur dengan menggunakan 4 indikator yaitu: 1) keuntungan, 2) kebebasan pribadi, 3) impian pribadi, dan 4) kemandirian (Herdjiono et al., 2018). Variabel kreativitas (X2) di ukur menggunakan 5 indikator, yaitu: 1) kemampuan dalam membuat sebuah perubahan, 2) memiliki suatu kepekaan, 3) mempunyai ide-ide yang baru, 4) optimis, dan 5) mampu bekerjasama (Wulandari, 2016). Pengukuran variabel inovasi (X3) menggunakan 3 indikator yaitu, 1) senang terhadap hal yang bersifat kreatif, 2) keinginan membuat sesuatu yang berbeda dengan orang lain, dan 3) senang melakukan percobaan (Bhandari (2006; Praswati, 2014; Wulandari, 2016). Adapun pengukuran modal usaha diukur dengan 3 indikator yaitu: 
1) memiliki modal (Rahmadi, Nur Afif \& Heryanto, 2016), 2) kemudahan akses mendapatkan modal (Indarti \& Kristiansen, 2003), 3) besarnya modal (Rosadi, 2019).

Teknik analisis datanya menggunakan statistik deskriptif (untuk melihat sebaran frekuensi dan kecenderungan variabel), dan regresi linear berganda (untuk menguji hipotesis). Karena data yang dihasilkan melalui pengumpulan kuisioner berdasarkan skala likert 1 sampai dengan 4 ini adalah data ordinal, sedangkan syarat data harus bersifat interval (Ningsih \& Dukalang, 2019), maka diperlukan MSI (Metode Suksesif Interval) untuk mentransformasikan data tersebut.

Tujuan dari transformasi data adalah untuk memperoleh koefisien korelasi yang besar agar data yang dikumpulkan memenuhi syarat model regresi yaitu model fit. Dengan begitu, kekeliruan intrepretasi dari model regresi dapat dihindari (Ningsih \& Dukalang, 2019). Selanjutnya, data yang didapatkan peneliti dari lapangan harus memenuhi beberapa asumi dasar yang ada pada model regresi linear berganda.

HASIL DAN PEMBAHASAN

Hasil Uji Validitas \& Reliabilitas Instrumen

Tabel 1. Uji Validitas Motivasi (X)

\begin{tabular}{lcccc}
\hline Item & $\mathrm{r}_{\text {hitung }}$ & $\mathrm{r}_{\text {tabel }}$ & $\begin{array}{c}\text { Sig }(2- \\
\text { tailed })\end{array}$ & Ket \\
\hline $1 \_1$ & 0,490 & &, 000 & \\
$1 \_2$ & 0,502 & &, 000 & \\
$1 \_3$ & 0,781 & &, 000 & \\
$1 \_4$ & 0,431 & &, 002 & \\
$1 \_5$ & 0,625 & &, 000 & \\
$1 \_6$ & 0,781 & $>0,279$ &, 000 & $\stackrel{0}{二}$ \\
$1 \_7$ & 0,794 & &, 000 & 0 \\
$1 \_8$ & 0,717 & &, 000 & \\
$1 \_9$ & 0,750 & &, 000 & \\
$1 \_10$ & 0,795 & &, 000 & \\
$1 \_11$ & 0,744 & &, 000 & \\
$1 \_12$ & 0,721 & &, 000 & \\
\hline
\end{tabular}

Tabel 1 di atas menunjukkan hasil bahwa semua item pernyataan pada variabel motivasi mempunyai $\mathrm{r}_{\text {hitung }}>\mathrm{r}_{\text {tabel }}$ dan sig (2tailed $)<0,05$, atau dinyatakan valid.

Tabel 2. Uji Validitas Kreativitas $\left(\mathrm{X}_{2}\right)$

\begin{tabular}{|c|c|c|c|c|}
\hline Item & $\mathrm{r}_{\text {hitung }}$ & $\mathrm{r}_{\text {tabel }}$ & $\begin{array}{l}\text { Sig (2- } \\
\text { tailed) }\end{array}$ & Ket \\
\hline $2 \_1$ & 0,777 & & ,000 & \\
\hline $2 \_2$ & 0,772 & & ,000 & \\
\hline $2 \_3$ & 0,825 & & ,000 & \\
\hline $2 \_4$ & 0,796 & & ,000 & \\
\hline $2 \_5$ & 0,587 & & ,000 & $\lesssim$ \\
\hline $2-6$ & 0,801 & $>0,219$ & ,000 & $\overline{2}$ \\
\hline $2 \_7$ & 0,456 & & ,001 & \\
\hline $2 \_8$ & 0,671 & & ,000 & \\
\hline $2 \_9$ & 0,646 & & ,000 & \\
\hline $2 \_10$ & 0,612 & &, 000 & \\
\hline
\end{tabular}

Sumber: data primer diolah, 2021

Tabel 2 di atas menunjukkan hasil bahwa semua item pernyataan pada variabel kreativitas mempunyai $\mathrm{r}_{\text {hitung }}>\mathrm{r}_{\text {tabel }}$ dan sig (2-tailed) < 0, 05, atau dinyatakan valid.

Tabel 3. Uji Validitasi Inovasi $\left(\mathrm{X}_{3}\right)$

\begin{tabular}{|c|c|c|c|c|}
\hline Item & $\mathrm{r}_{\text {hitung }}$ & $\mathrm{r}_{\text {tabel }}$ & $\begin{array}{l}\text { Sig (2- } \\
\text { tailed) }\end{array}$ & Ket \\
\hline $3 \_1$ & 0,754 & & ,000 & \\
\hline $3 \_2$ & 0,696 & & ,000 & \\
\hline $3 \_3$ & 0,831 & & ,000 & き. \\
\hline $3 \_4$ & 0,809 & $>0,279$ & 000 & \\
\hline $3 \_5$ & 0,838 & & ,000 & \\
\hline $3 \_6$ & 0,722 & & ,000 & \\
\hline
\end{tabular}

Sumber: data primer diolah, 2021

Tabel 3 di atas menunjukkan hasil bahwa semua item pernyataan pada variabel inovasi mempunyai $\mathrm{r}_{\text {hitung }}>\mathrm{r}_{\text {tabel }}$ dan sig (2tailed) $<0,05$, atau dinyatakan valid.

Tabel 4. Uji Validitas Modal Usaha $\left(\mathrm{X}_{4}\right)$

\begin{tabular}{|c|c|c|c|c|}
\hline Item & $\mathrm{r}_{\text {hitung }}$ & $\mathrm{r}_{\text {tabel }}$ & $\begin{array}{l}\text { Sig }(2- \\
\text { tailed) }\end{array}$ & Ket \\
\hline $4 \_1$ & 0,777 & & ,000 & \\
\hline $4 \_2$ & 0,772 & & ,000 & \\
\hline $4 \_3$ & 0,825 & $>0.279$ & ,000 & 巳. \\
\hline $4 \_4$ & 0,796 & $>0,219$ & ,000 & $\overrightarrow{0}$ \\
\hline $4 \_5$ & 0,587 & & ,000 & \\
\hline $4 \_6$ & 0,801 & &, 000 & \\
\hline
\end{tabular}

Sumber: data primer diolah, 2021

Tabel 4 di atas menunjukkan hasil bahwa semua item pernyataan pada variabel modal usaha mempunyai $\mathrm{r}_{\text {hitung }}>\mathrm{r}_{\text {tabel }}$ dan sig (2-tailed) $<0,05$, atau dinyatakan valid. 
Tabel 5. Uji Validitas Minat Berwirausaha (Y)

\begin{tabular}{|c|c|c|c|c|}
\hline Item & $\mathrm{r}_{\text {hitung }}$ & $\mathrm{r}_{\text {tabel }}$ & $\begin{array}{l}\text { Sig (2- } \\
\text { tailed) }\end{array}$ & Ket \\
\hline $5 \_1$ & 0,644 & &, 000 & \\
\hline $5 \_2$ & 0,752 & & ,000 & \\
\hline $5 \_3$ & 0,687 & & ,000 & \\
\hline $5 \_4$ & 0,459 & & ,000 & \\
\hline $5 \_5$ & 0,449 & & ,000 & $<$ \\
\hline $5 \_6$ & 0,517 & $>0,279$ & ,000 & 气. \\
\hline $5 \_7$ & 0,697 & & ,001 & \\
\hline $5 \_8$ & 0,610 & & ,000 & \\
\hline $5 \_9$ & 0,526 & & ,000 & \\
\hline 5_10 & 0,625 & & ,000 & \\
\hline $5 \_11$ & 0,596 & & ,000 & \\
\hline
\end{tabular}

Sumber: data primer diolah, 2021

Tabel 5 di atas menunjukkan hasil bahwa semua item pernyataan pada variabel minat berwirausaha mempunyai $r_{\text {hitung }}>r_{\text {tabel }}$ dan sig (2-tailed) $<0$, 05, atau dinyatakan valid.

Tabel 6. Uji Reliabilitas

\begin{tabular}{|c|c|c|}
\hline Variabel & Cronbach's alpha & Hasil \\
\hline X1_Mot & ,890 & \\
\hline X2_Kre & ,868 & $\underset{0}{2}$ \\
\hline X3_Ino & ,866 & $\ddot{\ddot{g}}$ \\
\hline X4_Mod & ,737 & ⿷ \\
\hline Y_Min & ,817 & \\
\hline
\end{tabular}

Sumber: data primer diolah, 2021

Dari Tabel 6 membuktikan bahwa semua variabel memperoleh nilai cronbach's alpha $>$ 0,6 atau dapat dinyatakan reliabel .

\section{Gambaran Umum Responden}

Di bawah ini merupakan gambaran umum responden:

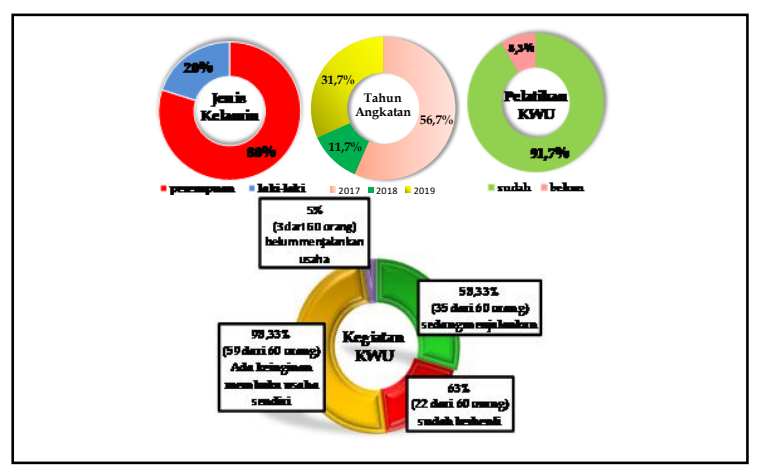

Gambar 2. Gambaran Umum Responden
Gambar 2 memperlihatkan bahwa jumlah responden telah memenuhi proporsi yang telah ditetapkan yaitu sebesar 60 responden. Dimana dari 60 responden tersebut, terdiri dari $80 \%$ (48 orang) berjenis kelamin perempuan dan sisanya sebesar $20 \%$ (12 orang) adalah laki-laki. Adapun komposisi responden dalam penelitian ini terdiri dari 56,7\% (34 mahasiswa angkatan 2017), 11,7\% (7 mahasiswa angkatan 2018), dan 31,7\% (19 mahasiswa angkatan 2019).

Selanjutnya, berdasarkan keikutsertaan responden terhadap pelatihan KWU didapat hasil bahwa mayoritas mahasiswa Prodi Pendidikan Ekonomi UNESA telah mengikuti kegiatan pelatihan seminar KWU (Kewirausahaan) yaitu sebesar 91,7\%. Sedangkan berdasarkan pada kegiatan usaha yang telah dijalankan, terdapat 59 dari 60 responden memiliki keinginan untuk membuka usaha sendiri. Namun, untuk sekarang ini masih terdapat 35 responden yang sedang menjalankan kegiatan usaha atau bisnis, 22 responden telah berhenti menjalankan kegiatan usaha yang sebelumnya telah dijalankan dan sisanya sebanyak 3 responden belum menjalankan kegiatan usaha.

Hal di atas memperlihatkan bahwa tidak semua mahasiswa yang memiliki keinginan untuk membuka usaha, mengaplikasikan keinginannnya ke dalam praktik nyata. Sedangkan mereka yang sudah menjalankan kegiatan usaha pun, sebagian ada yang sudah berhenti.

\section{Gambaran Kecenderungan Variabel}

Di bawah ini disajikan statistik deskriptif data variabel penelitian:

Tabel 7. Statistik Deskriptif

\begin{tabular}{lccccc}
\hline & N & Range & Min & Max & Mean \\
\hline X1_Mot & 60 & 15 & 33 & 48 & 41,42 \\
X2_Kre & 60 & 18 & 22 & 40 & 32,72 \\
X3_Ino & 60 & 8 & 16 & 24 & 21,10 \\
X4_Mod & 60 & 12 & 12 & 24 & 16,68 \\
Y_Min & 60 & 25 & 19 & 44 & 34,68 \\
Valid N & 60 & & & & \\
\hline \multicolumn{5}{l}{ Sumber: data primer diolah, 2021 }
\end{tabular}




\section{Minat Berwirausaha}

Berdasarkan Tabel 7 didapat nilai minat berwirausaha mempunyai range $=25$, nilai minimum $=19$, dan nilai maximum $=$ 44 , serta mean $=34,68$. Sehingga distribusi kecenderungan variabel minat berwirausaha adalah:

Tabel 8. Minat Berwirausaha (Y)

\begin{tabular}{llcc}
\multicolumn{1}{c}{ Rentang } & \multicolumn{1}{c}{ Kategori } & F & $\%$ \\
\hline Y $>38$ & Sangat tinggi & 16 & $26,7 \%$ \\
$34<\mathrm{Y}<38$ & Tinggi & 17 & $28,3 \%$ \\
$29<\mathrm{Y}<34$ & Sedang & 23 & $38,3 \%$ \\
$25<\mathrm{Y}<29$ & Rendah & 3 & $5 \%$ \\
$\mathrm{Y}<25$ & Sangat rendah & 1 & $1,7 \%$ \\
Jumlah & & 60 & $100 \%$ \\
\hline
\end{tabular}

Sumber: data primer diolah, 2021

Pada Tabel 7 nilai mean variabel minat berwirausaha $=34,68$, jika dikategorikan sesuai Tabel 8, maka berada pada rentang antara $34<\mathrm{Y}<38$. Sehingga bisa diartikan bahwa minat berwirausaha mahasiswa Prodi Pendidikan Ekonomi UNESA tergolong tinggi.

\section{Motivasi}

Pada Tabel 7 variabel motivasi memperoleh nilai range $=15$, nilai minimum $=33$, dan nilai maximum $=48$, serta mean $=$ 41,42. Dari perolehan ini, kecenderungan variabelnya adalah:

Tabel 9. Motivasi (X1)

\begin{tabular}{llcc}
\hline \multicolumn{1}{c}{$\begin{array}{c}\text { Rentang } \\
\text { Nilai }\end{array}$} & \multicolumn{1}{c}{ Kategori } & $\mathrm{f}$ & $\%$ \\
\hline $\mathrm{X} 1>44$ & Sangat tinggi & 18 & $30 \%$ \\
$42<\mathrm{X} 1<44$ & Tinggi & 11 & $18,3 \%$ \\
$39<\mathrm{X} 1<42$ & Sedang & 16 & $26,7 \%$ \\
$37<\mathrm{X} 1<39$ & Rendah & 10 & $16,7 \%$ \\
$\mathrm{X} 1<37$ & Sangat rendah & 5 & $8,33 \%$ \\
Jumlah & & 60 & $100 \%$ \\
\hline
\end{tabular}

Sumber: data primer diolah, 2021

Nilai mean variabel motivasi $=41,42$, jika dikategorikan sesuai Tabel 9, berada pada rentang $39<\mathrm{X} 1<42$. Sehingga dapat diartikan bahwa motivasi mahasiswa Prodi Pendidikan Ekonomi UNESA tergolong sedang.

\section{Kreativitas}

Berdasarkan Tabel 7, didapat nilai range $=18$, nilai minimum $=22$, maximum $=40$, dan mean $=32,72$. Dari nilai ini, distribusi frekuensi kecenderungan variabel kreativitas adalah:

Tabel 10. Variabel Kreativitas (X2)

\begin{tabular}{llcc}
\hline $\begin{array}{c}\text { Rentang } \\
\text { Nilai }\end{array}$ & \multicolumn{1}{c}{ Kategori } & F & $\%$ \\
\hline X2 $>36$ & Sangat tinggi & 18 & $30 \%$ \\
$33<\mathrm{X} 2<36$ & Tinggi & 10 & $16,7 \%$ \\
$30<\mathrm{X} 2<33$ & Sedang & 19 & $31,7 \%$ \\
$27<\mathrm{X} 2<30$ & Rendah & 9 & $15 \%$ \\
$\mathrm{X} 2<27$ & Sangat rendah & 4 & $6,6 \%$ \\
Jumlah & & 60 & $100 \%$ \\
\hline
\end{tabular}

Sumber: data primer diolah, 2021

Pada Tabel 7, mean variabel kreativitas $=32,72$. Jika dikategorikan sesuai Tabel 10, berada pada rentang $30<\mathrm{X} 2<33$. Sehingga dapat diartikan bahwa kreativitas mahasiswa Prodi Pendidikan Ekonomi UNESA tergolong sedang.

\section{Inovasi}

Pada Tabel 7 didapat nilai range $=8$, nilai minimum $=16$, nilai maximum $=24$, dan mean $=21,10$. Sehingga distribusi frekuensi kecenderungannya adalah:

Tabel 11. Inovasi (X3)

\begin{tabular}{llcc}
\hline \multicolumn{1}{c}{$\begin{array}{c}\text { Rentang } \\
\text { Nilai }\end{array}$} & \multicolumn{1}{c}{ Kategori } & $\mathrm{f}$ & $\%$ \\
\hline $\mathrm{X} 3>22$ & Sangat tinggi & 31 & $51,7 \%$ \\
$21<\mathrm{X} 3<22$ & Tinggi & 5 & $8,3 \%$ \\
$19<\mathrm{X} 3<21$ & Sedang & 14 & $23,3 \%$ \\
$18<\mathrm{X} 3<19$ & Rendah & 6 & $10 \%$ \\
$\mathrm{X} 3<18$ & Sangat rendah & 4 & $6,7 \%$ \\
Jumlah & & 60 & $100 \%$ \\
\hline
\end{tabular}

Sumber: data primer diolah, 2021

Pada Tabel 7 mean variabel inovasi $=$ 21,10. Sehingga jika dikategorikan sesuai Tabel 11, maka berada pada rentang $21<\mathrm{X} 3<22$. Artinya, inovasi mahasiswa Prodi Pendidikan Ekonomi UNESA tergolong tinggi. Hal ini disebabkan karena pada item pernyataan variabel inovasi dalam kuisioner, rata-rata memperoleh frekuensi jawaban sangat setuju yang lebih besar dari 
$50 \%$ dan hanya terdapat 1 item pernyataan saja yang memperoleh frekuensi jawaban sangat setuju yang berada dibawah angka $50 \%$.

\section{Modal Usaha}

Pada Tabel 7 variabel modal usaha (X4) memperoleh nilai range $=12$, nilai $\min$ $=12$, nilai $\max =24$, dan mean $=16,68$. Sehingga distribusi kecenderungan variabel modal usaha adalah sebagai berikut:

Tabel 12. Modal Usaha (X4)

\begin{tabular}{llcc}
\hline $\begin{array}{c}\text { Rentang } \\
\text { Nilai }\end{array}$ & \multicolumn{1}{c}{ Kategori } & f & $\%$ \\
\hline X4 $>21$ & Sangat tinggi & 6 & $10 \%$ \\
$19<\mathrm{X} 4<21$ & Tinggi & 7 & $11,7 \%$ \\
$17<\mathrm{X} 4<19$ & Sedang & 14 & $23,3 \%$ \\
$15<\mathrm{X} 4<17$ & Rendah & 22 & $36,7 \%$ \\
$\mathrm{X} 4<15$ & Sangat rendah & 11 & $18,3 \%$ \\
Jumlah & & 60 & $100 \%$ \\
\hline Sum
\end{tabular}

Sumber: data primer diolah, 2021

Pada Tabel 7, mean variabel modal usaha $=16,68$. Nilai tersebut jika dikategorikan sesuai dengan Tabel 12, maka berada pada rentang antara $15<\mathrm{X} 4<17$. Kesimpulannya, modal usaha mahasiswa PE Prodi Pendidikan Ekonomi UNESA tergolong rendah. Hal ini disebabkan karena pada item pernyataan variabel modal usaha yang ada dalam kuisioner, rata-rata mendapat frekuensi jawaban sangat setuju yang relatif kecil $(<50 \%)$ jika dibandingkan dengan variabel lainnya.

\section{Uji Asumsi Klasik}

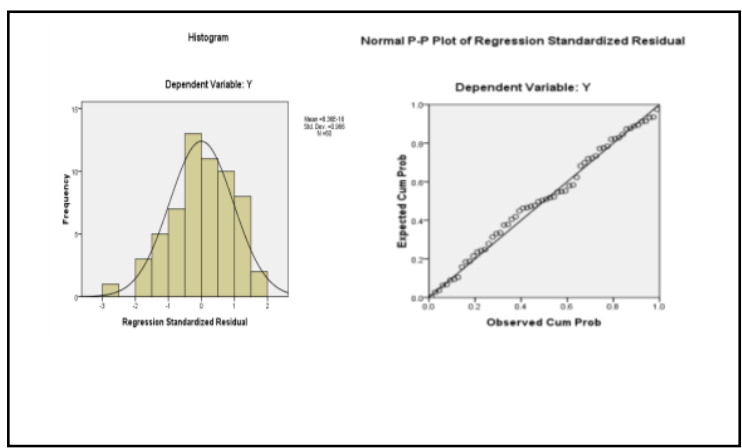

Gambar 3. Histogram dan P-Plot
Tabel 13. One sample Test_(Kolmogorov. Smirnov)

\begin{tabular}{llr}
\hline & \multicolumn{2}{c}{ Unstandardized Residual } \\
\hline $\mathrm{N}$ & 60 \\
Normal & Mean &, 0000000 \\
Parameters $^{a}$ & & \\
& $\quad$ Std. Deviation & 4,23621775 \\
Kolmogorov-Smirnov $Z$ &, 487 \\
Asymp. Sig. (2-tailed) &, 972 \\
\hline a. Test distribution is Normal & \\
Sumber: output Pengolahan SPSS 21 &
\end{tabular}

Berdasarkan Gambar 2 menunjukkan bahwa grafik histogram tidak mengalami kemencengan (kiri/kanan). Begitupun dengan grafik $P$-Plot, semua titik-titik yang ada menyebar mengikuti garis diagonal. Selanjutnya, berdasarkan Tabel 13 didapat nilai asymp. Sig yang melebihi angka 0,05 $(5 \%)$ yaitu sebesar $0,972(0,972>0,05)$. Perolehan ini menjelaskan bahwa data berdistribusi normal.

Tabel 14. Glejser Test

\begin{tabular}{lrr}
\hline \multicolumn{3}{c}{ Coefficients $^{a}$} \\
\hline Model & $T$ & \multicolumn{1}{c}{ Sig. } \\
\hline 1 (Constant) &, 111 &, 912 \\
Motivasi &, 590 &, 558 \\
Kreativitas &,- 044 &, 965 \\
Inovasi & 1,646 &, 105 \\
Modal usaha & $-1,336$ &, 187 \\
a. Dependent Variable: Abs_Res & \\
\hline
\end{tabular}

Sumber: Output Pengolahan SPSS 21

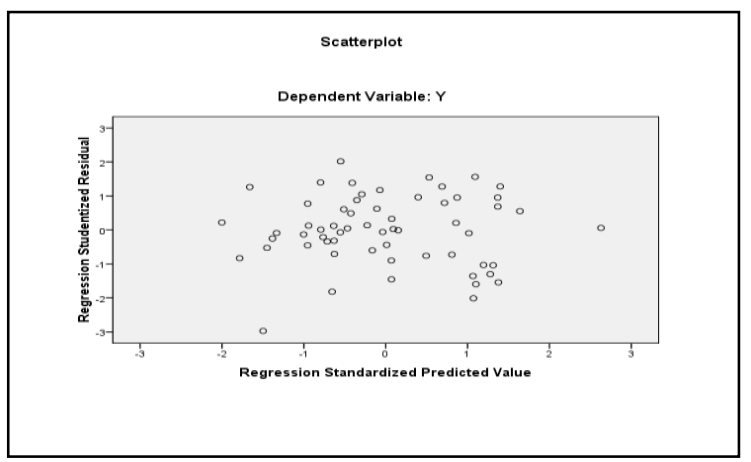

Gambar 4. Scatterplot

Hasil uji heteroskedastisitas Tabel 14 memperlihatkan bahwa model tidak teridentifikasi gejala heteroskedastisitas. Hal ini dibuktikan oleh hasil uji glejser dan scatterplot. Berdasarkah hasil uji glejser 
semua variabel independen (motivasi, kreativitas, inovasi, dan modal usaha) memiliki nilai sig. di atas 0,05 (5\%). Sedangkan berdasarkan scatterplot terlihat bahwa titik yang ada pada Gambar 4 semuanya tersebar acak.

Tabel 15. Uji Multikolinearitas

\begin{tabular}{lcc}
\hline \multicolumn{3}{c}{ Coefficients $^{a}$} \\
\cline { 2 - 3 } Model & \multicolumn{3}{c}{ Collinearity $^{\text {Tolerance }}$} & VIF \\
\hline 1 (Constant) & & \\
Motivasi &, 515 & 1,941 \\
Kreativitas &, 402 & 2,487 \\
Inovasi &, 436 & 2,292 \\
Modal usaha &, 868 & 1,152 \\
\hline
\end{tabular}

a. Dependent Variable: Minat berwirausaha Sumber: Output Pengolahan SPSS 21

Hasil uji multikolinearitas Tabel 15 menjelaskan bahwa tidak adanya gejala multikolinearitas pada model, karena keseluruhan variabel independennya memiliki nilai toleransi $>0,1$ dan variance inflation factor $<10$.

Tabel 16. Uji Linearitas

\begin{tabular}{lr}
\hline Variabel & $\begin{array}{c}\text { Nilai Sig. deviation from } \\
\text { linearity }\end{array}$ \\
\hline X1 terhadap Y & 0,369 \\
X2 terhadap Y & 0,308 \\
X3 terhadap Y & 0,484 \\
X4 terhadap Y & 0,461 \\
\hline
\end{tabular}

Sumber: Output Pengolahan SPSS 21

Dari uji linearitas di atas diperoleh hasil bahwa nilai sig. dev.from linearity pada setiap variabel bebas > 5\% $(0,05)$, artinya hubungan semua variabel bebas (motivasi, kreativitas, inovasi, dan modal usaha) terhadap variabel terikatnya (minat berwirausaha) adalah linear .

\section{Hasil Analisis Regresi Linier Berganda}

Tabel 17. Hasil Uji t (Parsial)

\begin{tabular}{lcclc}
\hline \multicolumn{5}{c}{ Coefficients $^{a}$} \\
\hline \multicolumn{5}{c}{$\begin{array}{c}\text { Unstandardized } \\
\text { Coefficients }\end{array}$} \\
\hline Model & $B$ & $\begin{array}{c}\text { Std. } \\
\text { Error }\end{array}$ & $T$ & Sig. \\
\hline 1 & 3,822 & 4,455 &, 858 &, 395
\end{tabular}

\begin{tabular}{|c|c|c|c|c|c|}
\hline \multirow{2}{*}{\multicolumn{6}{|c|}{$\begin{array}{c}\text { Coefficients }^{a} \\
\text { Unstandardized } \\
\text { Coefficients }\end{array}$}} \\
\hline & & & & & \\
\hline Model & & $\begin{array}{r}S \\
E r\end{array}$ & $\begin{array}{l}t d . \\
\text { tror }\end{array}$ & $T$ & Sig. \\
\hline \multicolumn{6}{|l|}{ Konstan } \\
\hline \multicolumn{2}{|l|}{$\mathrm{X} 1$} & ,429 & 150 & 2,868 & ,006 \\
\hline \multicolumn{2}{|l|}{$\mathrm{X} 2$} &, 345 & 156 & 2,214 & 031 \\
\hline \multicolumn{2}{|l|}{ X3 } &,- 247 & 245 & & ,318 \\
\hline \multicolumn{2}{|l|}{$\mathrm{X} 4$} &, 582 & 195 & 2,985 & ,004 \\
\hline \multicolumn{6}{|c|}{ a. Dependent Variable: $\mathrm{Y}$} \\
\hline \multicolumn{6}{|c|}{ Sumber: Output Pengolahan SPSS 21} \\
\hline \multicolumn{6}{|c|}{ Tabel 18. $\mathrm{R}^{2}$} \\
\hline \multicolumn{6}{|c|}{ Model Summary ${ }^{a}$} \\
\hline Model & $R$ & $\begin{array}{c}R \\
\text { square }\end{array}$ & & $\begin{array}{l}\text { usted } \\
R \\
\text { uare }\end{array}$ & $\begin{array}{c}\text { Std. } \\
\text { Error } \\
\text { of the } \\
\text { Estimae }\end{array}$ \\
\hline 1 &, $701^{\mathrm{a}}$ & ,491 & & ,454 & 4,38756 \\
\hline
\end{tabular}

a. Prediktors: (Constant), X1, X2, X3, X4

b. Dependent Variable: Y

Sumber: Output Pengolahan SPSS 21

Tabel 19. F-test

\begin{tabular}{lrll}
\hline \multicolumn{4}{c}{ ANOVA $^{b}$} \\
\hline \multicolumn{1}{c}{ Model } & Df & $F$ & Sig. \\
\hline 1 Regression & 4 & 13,287 &, $000^{\mathrm{a}}$ \\
Residual & 55 & & \\
Total & 59 & & \\
\hline a. Prediktors: (Constant), X1, X2, X3, X4 \\
b. Dependent Variable: Y \\
Sumber: Output Pengolahan SPSS 21
\end{tabular}

Berdasarkan nilai unstandardized coefficients Tabel 17, persamaannya adalah:

$$
\begin{aligned}
\mathrm{Y}= & 3,822(\mathrm{C})+0,429 \mathrm{X}_{1}+0,345 \mathrm{X}_{2}-0,247 \mathrm{X}_{3} \\
& +0,582 \mathrm{X}_{4}+e
\end{aligned}
$$

Nilai C (konstanta) sebesar 3,822 atau apabila variabel bebas (motivasi, kreativitas, inovasi \& modal usaha) dianggap konstan (tidak mengalami perubahan), maka besarnya minat berwirausaha mahasiswa Prodi Pendidikan Ekonomi UNESA adalah 3,822 .

Variabel motivasi, memiliki nilai $\beta_{1} /$ (koefisien regresi) sebesar 0,429 . Hal ini berarti jika terjadi 1 perubahan pada variabel motivasi dan variabel bebas lainnya 
(kreativitias, inovasi, modal usaha dianggap tetap, maka minat berwirausaha juga akan mengalami perubahan sebesar 0,429 dan ini signifikan. Sehingga tingginya motivasi akan memacu meningkatnya minat berwirausaha mahasiswa Prodi Pendidikan Ekonomi UNESA.

Variabel kreativitas mempunyaii nilai $\beta_{2} /$ (koefisien regresi) sebesar 0,345 . Hal ini berarti jika terjadi 1 perubahan pada variabel kreativitas dan variabel lainnyadianggap constant, minat berwirausaha juga akan mengalami perubahan sebesar 0,345 dan ini signifikan. Tigginya tingkat kreativitas akan menekan terjadinya peningkatan pada minat berwirausaha mahasiswa Prodi Pendidikan Ekonomi UNESA.

Variabel inovasi memiliki nilai $\beta_{3} /$ (koefisien regresi) sebesar $-0,247$. Hal ini berarti jika terjadi 1 perubahan pada variabel inovasi dan variabel bebas yang lainnya tidak berubah, minat berwirausaha justru menurun atau berkurang 0,247 , namun hal ini tidak signifikan. Sehingga tingkat inovasi belum mampu mendorong secara optimal terjadinya peningkatan pada minat berwirausaha mahasiswa Prodi Pendidikan Ekonomi UNESA.

Variabel modal usaha memiliki nilai $\beta_{4} /$ (koefisien regresi) sebesar 0,582 . Hal ini berarti jika terjadi 1 perubahan pada variabel modal usaha dan variabel bebas lainnya dianggap tidak berubah, minat berwirausaha juga akan berubah sebesar 0,582 dan ini signifikan. Banyaknya modal usaha akan mendorong terjadinya peningkatan minat berwirausaha berwirausaha mahasiswa Prodi Pendidikan Ekonomi UNESA.

\section{Pengaruh Motivasi, Kreativitas, Inovasi, dan Modal Usaha terhadap minat berwirausaha}

Berdasarkan Tabel 19, diperoleh nilai $F_{\text {hitung }}=13,287$ yang lebih besar dari nilai $\mathrm{F}_{\text {tabel }}=2,54$ dan sig.F-test $=0,000$ yang dibawah angka 5\%. Kesimpulannya adalah ada pengaruh positif signifikan variabel motivasi, kreativitas, inovasi dan modal usaha secara simultan terhadap variabel minat berwirausaha mahasiswa Prodi
Pendidikan Ekonomi UNESA. Hasil ini sehaluan dengan penelitiannya Anggraini (2017); Mahanani dan Sari, (2018); Tanusi \& Laga (2020), yang menerangkan bahwa minat berwirausaha dapat dipengaruhi oleh berbagai aspek, diantaranya motivasi, kreativitas, inovasi, dan modal usaha.

Hasil olah data menunjukkan bahwa indikator 1 variabel minat berwirausaha memperoleh rata-rata skor terendah $=2,82$. Sedangkan untuk skor rata-rata tertinggi berada di indikator $2=3,413$. Dan untuk indikator 3 memperoleh nilai rata-rata skor > indikator 1 , namun < indikator 3 yaitu sebesar 3,15. Perolehan hasil ini menjelaskan bahwa upaya yang sedang maupun sudah direncanakan mahasiswa Prodi Pendidikan Ekonomi UNESA untuk melakukan aktivitas kewirausahaan dan keinginan untuk menjadikan wirausaha sebagai pilihan karir di masa depan lebih besar daripada upaya mereka untuk mencoba melakukan aktivitas kewirausahaan.

Berdasarkan pada temuan di atas, penyebab berpengaruhnya semua variabel bebas terhadap minat berwirausaha mahasiswa Prodi Pendidikan Ekonomi UNESA adalah dengan adanya motivasi akan mendorong mahasiswa bekerja lebih keras merealisasikan apa yang mereka inginkan termasuk keinginan untuk menjalankan usaha. Hal ini tidak cukup dengan motivasi saja, mahasiswa Prodi pendidikan Ekonomi juga harus berbekal kemampuan yang kreatif dan inovatif serta modal usaha yang cukup agar mampu menghadirkan maupun menangkap dan mengeksekusi setiap peluang usaha yang ada. Semua aspek ini (motivasi, kreativitas, inovasi, dan modal usaha) adalah hal yang harus dimiliki mahasiswa Prodi Pendidikan Ekonomi UNESA yang memiliki minat terhadap wirausaha. Hasil penelitian ini menjelaskan bahwa motivasi dan kreativitas yang sedang, inovasi yang tinggi serta modal usaha yang rendah mengakibatkan minat berwirausaha mahasiswa Prodi Pendidikan Ekonomi UNESA memasuki kategori tinggi. Namun, kategori tinggi yang dimaksud disini masih banyak yang berada pada tahap 
merencanakan. Hal ini terbukti pada perolehan skor rata-rata pada masing-masing indikator minat berwirausaha (indikator 1 dan 2 pada variabel minat berwirausaha memiliki skor rata-rata yang lebih tinggi dari indikator 3). Dimana mahasiswa Prodi Pendidikan Ekonomi UNESA yang telah berupaya untuk mencoba melakukan kegiatan kewirausahaan jumlahnya lebih sedikit dari jumlah mahasiswa yang sedang ataupun sudah merencanakan upaya untuk melakukan kegiatan wirausaha.

Selanjutnya, berdasarkan perolehan koefisien determinasi yang disesuaikan pada tabel 18 sebesar 45,4\%, menjelaskan bahwa secara simultan keempat variabel yang dimasukkan ke dalam model penelitian (motivasi, kreativitas, inovasi, dan modal usaha) memiliki kemampuan dalam menjelaskan perubahan nilai pada variabel minat berwirausaha mahasiswa Prodi Pendidikan Ekonomi UNESA yaitu 0,454 $(45,4) \%$. Sedangkan sebesar $54,6 \%$ dipengaruhi oleh variabel lain.

\section{Pengaruh Motivasi terhadap Minat Berwirausaha}

Pada Tabel 17 diperoleh nilai sig. Ttest variabel motivasi $=0,006$ yang kurang dari $\alpha=5 \%$ dan $\quad T_{\text {hitung }}=2,868 \quad>$ $\mathrm{T}_{\text {tabel }}=2,004404$. Sehingga dapat diartikan bahwa hasil T-test ini membuktikan ada pengaruh positif signifikan variabel motivasi secara parsial terhadap variabel minat berwirausaha. Ini selaras dengan penelitian Aqmala et al. (2020); Mahanani dan Sari (2018); Nadya dkk, (2019); Rifkhan (2017); Tanusi et al. (2020); Wijayangka dkk (2018) yang sama-sama menyatakan hasil yang demikian. Dengan begitu, hasil penelitian ini tidak sefrekuensi dengan penelitiannya Dzulfikri, Ahmad dan Kusworo (2017); Rosmiati et al. (2015) yang menyatakan bahwa motivasi tidak berdampak signifikan pada minat berwirausaha.

Berpengaruhnya motivasi terhadap minat berwirausaha pada hasil penelitian ini disebabkan karena dengan adanya motivasi berwirausaha, mahasiswa Prodi Pendidikan Ekonomi UNESA terdorong untuk bekerja keras agar memperoleh beberapa hal yang mereka inginkan dengan jalur menjalankan usaha atau berwirausaha. Terdapat beberapa aspek yang memotivasi mahasiswa menaruh minat pada wirausaha, diantaranya adalah: 1) keinginan untuk menjadi pribadi yang mandiri, 2) keinginan untuk memperoleh kebebasan dan mewujudkan impian pribadi, 3) keinginan untuk mendapatkan keuntungan.

Hasil olah data yang dilakukan menunjukkan bahwa indikator 4 memperoleh skor mean tertinggi $=3.6333$. Sedangkan mean skor terendah pada variabel motivasi berada pada indikator 1 yaitu sebesar 3,1667. Selanjutnya, untuk indikator 2 dan indikator 3 mendapat perolehan nilai rata-rata skor tertinggi kedua setelah indikator 4, yaitu masing-masing sebesar 3,5333.

Hasil di atas menunjukkan bahwa motivasi terkuat diurutan 1 , yang dapat mendorong mahasiswa Prodi Pendidikan Ekonomi UNESA berwirausaha adalah karena dengan berwirausaha akan menjadikan mereka sebagai pribadi yang mandiri (dapat melakukan banyak hal dan dapat membiayai kebutuhan hidup sendiri). Hal ini diperkuat dalam item pernyataan indikator 1 yang menyatakan "dengan menjadi wirausahawan dapat melatih kemandirian saya" mendapat frekuensi jawaban sangat setuju dan setuju sebesar $100 \%$.

Motivasi terkuat diurutan 2 adalah kebebasan pribadi dan impian pribadi. Mahasiswa Prodi Pendidikan Ekonomi UNESA termotivasi untuk berwirausaha karena dengan berwirausaha mereka dapat memperoleh kebebasan pribadi dan dapat merealisasikan impian pribadinya. Hal ini didukung oleh beberapa item pernyataan pada indikator 2 dan indikator 3, diantaranya pada item pernyataan yang menyatakan "dengan berwirausaha mereka bebas mengatur waktunya" mendapat frekuensi jawaban sangat setuju dan setuju sebanyak 95\%. Selanjutnya item pernyataan pada indikator 3 yang menyatakan "saya ingin menjadi wirausahawan muda yang sukses" mendapat frekuensi jawaban sangat setuju 
sebanyak 83,3\% dan item pernyataan "dengan berwirausaha dapat membuka lapangan pekerjaan" memperoleh frekuensi jawaban sangat setuju sebanyak $78,3 \%$. Kemudian, pada item pernyataan "dengan berwirausaha saya dapat merealisasikan mimpi saya menjadi orang kaya" mendapat frekuensi jawaban sangat setuju dan setuju sebanyak $85 \%$.

Motivasi terkuat diurutan terakhir adalah keuntungan. Mahasiswa Prodi Pendidikan Ekonomi UNESA terdorong untuk berwirausaha adalah karena dengan berwirausaha mereka akan mendapat beberapa keuntungan. Hal ini diperkuat dengan beberapa item pernyataan pada indikator 1, diantaranya pada item pernyataan "dengan berwirausaha saya dapat memperoleh penghasilan sendiri" dan item pernyataan "dengan berwirausaha saya akan mendapat pengalaman bisnis yang banyak" mendapat frekuensi jawaban sangat setuju masing-masing sebanyak $60 \%$.

\section{Pengaruh Kreativitas terhadap Minat Berwirausaha}

Berdasarkan hasil T-test Tabel 17 diperoleh nilai sig. T-test pada variabel kreativitas sebesar 0,031 yang kurang dari $\alpha$ $=0,05$ dan $\mathrm{T}_{\text {hitung }}=2,214>\mathrm{T}_{\text {tabel }}=2,004404$. Sehingga kesimpulannya adalah ada pengaruh positif signifikan variabel kreativitas secara parsial terhadap minat berwirausaha. Ini mendukung penelitiannya Imambachri et al. (2020); Mahanani dan Sari (2018); Nadya dkk (2019); Rahmadi, Nur Afif dan Heryanto (2016) yang sama-sama menyatakan hasil yang serupa. Dengan begitu, hasil ini bertolak belakang dengan penelitiannya Noviasari (2018) yang mengungkap tidak adanya pengaruh signifikan antara kreativitas dengan minat berwirausaha.

Adanya pengaruh kreativitas terhadap minat berwirausaha mahasiswa Prodi Pendidikan Ekonomi UNESA dalam penelitian ini disebabkan karena dengan memiliki kreativitas, mahasiswa Prodi Pendidikan Ekonomi UNESA dapat menciptakan berbagai ide bisnis segar untuk menghadirkan ataupun menangkap peluang usaha. Dengan kepemilikan kreativitas ini mendorong mahasiswa Prodi Pendidikan Ekonomi UNESA untuk mewujudkan minatnya terhadap wirausaha. Sehinga tinggi rendahnya tingkat kreativitas mahasiswa Prodi Pendidikan Ekonomi UNESA akan ikut menentukan tinggi rendahnya tingkat minat berwirausaha. Karena kreativitas mahasiswa Prodi Pendidikan ekonomi masih berada pada kategori sedang, maka mengakibatkan indikator 3 pada minat berwirausaha memperoleh skor rata-rata yang kecil jika dibandingkan dengan indikator 1 dan 2 .

Berdasarkan olah data yang dilakukan, nilai rata-rata skor tertinggi di urutan pertama sebesar 3,4 pada indikator 5 . Hal ini berarti mahasiswa Pendidikan Ekonomi UNESA mempunyai kemampuan bekerjasama yang tinggi. Hal ini diperkuat oleh item pernyataan "saya sering bekerjasama dengan orang lain untuk menciptakan ide-ide yang kreatif" dan item pernyataan "saya mampu berkomunikasi dengan orang lain" mendapat frekuensi jawaban sangat setuju masing-masing sebesar $45 \%$ dan $60 \%$.

Selanjutnya, nilai rata-rata skor tertinggi di urutan kedua sebesar 3,3 berada pada indikator 1 dan indikator 3. Perolehan nilai ini dapat diartikan bahwa kemampuan mahasiswa Prodi Pendidikan Ekonomi UNESA dalam membuat perubahan dan menciptakan ide-ide bisnis yang baru belum sebesar kemampuan mereka dalam bekerjasama. Hal ini diperkuat pada item pernyataan "saya mampu membuat perubahan yang baru dan kreatif dalam menjalankan usaha" dan item pernyataan "saya mempunyai ide-ide bisnis yang baru untuk mengembangkan usaha" mendapat frekuensi jawaban sangat setuju masingmasing hanya sebesar $36,7 \%$.

Nilai rata-rata skor tertinggi di urutan ketiga sebesar 3,2 berada pada indikator 4 (optimis). Hal ini disebabkan karena pada item pernyataan "saya mudah menyerah dalam melaksanakan sesuatu hal" mendapat frekuensi jawaban sangat tidak setuju hanya 
sebesar 28,3\%. Selanjutnya, skor mean diurutan terakhir ada di indikator 2. Meskipun pada item pernyataan "saya peka terhadap peluang bisnis yang ada" mendapat frekuensi jawaban sangat setuju sebanyak $31,7 \%$. Namun, pada item pernyataan lainnya yang menyatakan "saya tanggap dalam mengubah suatu permasalahan menjadi peluang bisnis" hanya mendapat frekuensi jawaban sangat setuju sebanyak $25 \%$ saja. Hal ini menunjukkan bahwa kepekaan mahasiswa Prodi Pendidikan Ekonomi UNESA terhadap peluang bisnis yang ada belum dimanfaatkan dengan optimal.

\section{Pengaruh Inovasi terhadap Minat Berwirausaha}

Berdasarkan hasil T-test Tabel 17 diperoleh nilai sig. T-test $0,318>\alpha=0.05$ dan $\mathrm{T}_{\text {hitung }}=-1,009<\mathrm{T}_{\text {tabel }}=2,004404$. Sehingga kesimpulannya adalah secara parsial tidak adanya pengaruh signifikan antara variabel inovasi dengan minat berwirausaha. Hal ini memperkuat penelitian Noviasari (2018); Rahmadi, Nur Afif dan Heryanto (2016) yang menyatakan hasil yang sama. Dengan begitu, perolehan hasil ini tidak kompatibel dengan penelitiannya Mahanani dan Sari (2018) yang mengungkap adanya pengaruh signifikan inovasi dengan minat berwirausaha.

Rusdiana (2018) menjelaskan bahwa adanya kemampuan inovasi dapat memperbesar harapan keberhasilan suatu usaha. Dan keberhasilan ini yang menjadi harapan banyak orang termasuk mahasiswa Prodi Pendidikan Ekonomi UNESA yang menaruh minat untuk berwirausaha. Maka dari itu jika kemampuan inovasi belum terimplementasikan dengan baik pada usaha yang akan atau telah dijalankan, akan ada kemungkinan terjadinya ketidakmampuan seorang wirausahawan dalam mencoba melakukan ataupun mempertahankan suatu usaha yang akan atau telah dijalankannya. Dan alasan ini yang menjadikan inovasi tidak berpengaruh terhadap minat berwirausaha mahasiswa Prodi Pendidikan Ekonomi UNESA. Sebagaimana pada temuan yang diungkap dalam penelitian ini, yaitu upaya berinovasi yang sudah dilakukan oleh mahasiswa Prodi Pendidikan Ekonomi UNESA untuk memajukan usahanya masih belum sebanding dengan tingginya keinginan dan ketertarikan mereka untuk melakukan inovasi. Maka tidak heran jika mahasiswa Prodi Pendidikan Ekonomi UNESA yang sudah menjalankan kegiatan usaha, sebagian ada yang sekarang usahanya sudah berhenti. Padahal menurut Rusdiana (2018), pengimplementasian inovasi adalah hal yang sangat diperlukan untuk mengonversi ide menjadi lebih realistis. Sehingga jika mahasiswa Prodi Pendidikan Ekonomi UNESA ingin berhasil dalam berwirausaha, mereka harus mengaplikasikan inovasi yang baik ke dalam usahanya.

\section{Pengaruh Modal Usaha terhadap Minat Berwirausaha}

Berdasarkan hasil T-test Tabel 17 diperoleh nilai sig. T-test 0,004 yang kurang dari $\alpha=0.05$ dan $\mathrm{T}_{\text {hitung }}=2,985>\mathrm{T}_{\text {tabel }}=$ 2,004404. Sehingga kesimpulannya adalah secara parsial ada pengaruh positif signifikan antara variabel modal usaha dengan minat berwirausaha. Perolehan ini kompatibel dengan penelitiannya Anggraini (2017); Ibrahim (2020); Tanusi et al. (2020) yang sama-sama mengungkap hasil demikian. Dengan begitu, hasil ini kontras dengan hasil penelitiannya Rahmadi, Nur Afif dan Heryanto (2016); Yuliawan dan Ginting, (2015) yang mengungkap tidak adanya pengaruh antara modal usaha dengan minat berwirausaha. Pada penelitian ini menjelaskan bahwa adanya pengaruh positif signifikan modal usaha terhadap minat berwirausaha mahasiswa Prodi Pendidikan Ekonomi UNESA disebabkan karena untuk memulai mencoba melakukan kegiatan usaha diperlukan sejumlah modal usaha (uang) atau dengan kata lain sebelum memutuskan untuk melakukan sebuah usaha, mahasiswa Prodi Pendidikan Ekonomi harus memiliki modal usaha (uang) yang dapat dipakai untuk membiayai keperluan usahanya. Hal ini dibuktikan dengan salah satu temuan, yaitu masih belum cukup banyaknya modal usaha 
yang dimiliki mahasiswa Prodi Pendidikan Ekonomi UNESA mengakibatkan variabel minat berwirausaha pada indikator "upaya untuk mencoba melakukan aktivitas kewirausahaan" memperoleh skor mean terendah dari 2 indikator lainnya.

\section{Kesimpulan}

Berdasarkan hasil analisis yang dilakukan, maka dapat disimpulkan bahwa: 1) Motivasi, kreativitas, inovasi, dan modal usaha secara serentak berpengaruh positif signifikan pada minat berwirausaha mahasiswa Prodi Pendidikan Ekonomi UNESA, 2) Motivasi berpengaruh positif signifikan terhadap minat berwirausaha mahasiswa Prodi Pendidikan Ekonomi UNESA, 3) Kreativitas berpengaruh positif signifikan terhadap minat berwirausaha mahasiswa Prodi Pendidikan Ekonomi UNESA, 4) Inovasi tidak berpengaruh signifikan terhadap minat berwirauaha mahasiswa Prodi Pendidikan Ekonomi UNESA, 5) Modal usaha berpengaruh positif signifikan terhadap minat berwirauaha mahasiswa Prodi Pendidikan Ekonomi UNESA. Berdasarkan hasil tersebut, maka pihak Perguruan Tinggi sebaiknya mulai melakukan kegiatan yang dapat meningkatkan motivasi dan kreativitas mahasiswa yang bias dilakukan melalui kerjasama dengan dunia usaha maupun alumni, serta mulai mencoba membuka akses permodalan bagi mahasiswa misal melalui Koperasi Mahasiswa maupun kerjasaman dengan lembaga pembiayaan.

\section{DAFTAR PUSTAKA}

Alma, B. (2010). Kewirausahaan (Edisi Revisi). Bandung: CV Alfabeta.

Anggraini, P. (2017). Pengaruh Motivasi, Mental dan Modal Usaha Terhadap Mahasiswa Akuntansi untuk Berwirausaha (Studi Kasus Pada Mahasiswa Akuntansi Universitas Muhammadiyah Jember). Thesis. Universitas Muhammadiyah Jember,

Aqmala, D., Putra, F. I. F. S., \& Suseno, A. (2020). Faktor-faktor yang Membentuk Minat Berwirausaha Mahasiswa
Program Studi Manajemen Universitas Dian Nuswantoro. Dayasaing. Jurnal Manajemen Sumber Daya, 22(1), 6070.

Badan Pusat Statistik. (2020). Keadaan Ketenagakerjaan Indonesia Februari 2020. Berita Resmi Statistik, 40, 20.

Bhandari, N. C. (2006). Intention for entrepreneurship among students in India. Journal of Entrepreneurship, 15, 169-179

https://doi.org/10.1177/097135570601 500204.

Chen, M. H., Chang, Y. Y., Wang, H. Y., \& Chen, M. H. (2017). Understanding creative entrepreneurs' intention to quit: The role of entrepreneurial motivation, creativity, and opportunity. Entrepreneurship Research Journal, 7(3), 1-15. https://doi.org/10.1515/erj2016-0001

Dzulfikri, Ahmad dan Kusworo, B. (2017). Sikap, Motivasi, dan Minat Berwirausaha Mahasisawa di Surabaya. Jurnal Kebijakan \& Manajemen Publik, 5(2), 183-200. https://doi.org/10.21070/jkmp.v5i2.131 0

Gerardo, Barroso Tanoira F. (2017). Motivation for increasing creativity, innovation and entrepreneurship an Experience From The Classroom To Business Firms. Journal of Innovation Management, 5(3), 55-74. https://doi.org/10.24840/21830606_005.003_0005

Herdjiono, I., Puspa, Y. H., Maulany, G., \& Aldy, B. E. (2018). The Factors Affecting Entrepreneurship Intention. International Journal of Entrepreneurial Knowledge, 5(2), 515. https://doi.org/10.1515/ijek-20170007

Ibrahim, M. M. (2020). Pengaruh Kreatifitas, Lingkungan Sosial dan Keluarga, dan Modal terhadap Minat Wirausaha. Thesis. Universitas Ahmad Dahlan

Imambachri, S. H., Arifin, Z. Z., \& Pamulang, U. (2020). Pengaruh 
Karakter Individual dan Kreatifitas terhadap Minat Berwirausaha Mahasiswa D-III Sekretari Universitas Pamulang, e-Journal Apresiasi Ekonomi, 8(3), 372-382.

Indarti, N., \& Kristiansen, S. (2003). Determinants of the case of Norwegian students. Gadjah Mada International Journal of Business, 5(1), 79-95.

Karen Hapuk, M. S., Suwatno, S., \& Machmud, A. (2020). Efikasi Diri dan Motivasi: Sebagai Mediasi Pengaruh Pendidikan Kewirausahaan terhadap Minat Berwirausaha. Jurnal Riset Pendidikan Ekonomi, 5(2), 59-69. https://doi.org/10.21067/jrpe.v5i2.4577

Kumaran, M., \& Anand, P. R. (2016). Entrepreneurship motivation of fisheries graduates: An exploratory study. Journal of Extension Education, 28(1), 5579. https://doi.org/10.26725/jee.2016.1.28. 5579-5587

Larasati, D. Dwi. (2020). Pengaruh Status Sosial Ekonomi Orang Tua dan Pendidikan Kewirausahaan terhadap Minat Berwirausaha Mahasiswa Di Universitas Negeri Makassar. Jurnal Pendidikan Ekonomi, 8(1), 37. https://doi.org/10.26858/jnp.v8i1.1366 6

Mahanani, E., \& Sari, B. (2018). FaktorFaktor yang Mempengaruhi Minat Berwirausaha Mahasiswa Fakultas Ekonomi Universitas Persada Indonesia Y.A.I. Ikraith-Humaniora, 2(2), 31-40.

Mat, S. C., Maat, S. M., \& Mohd, N. (2015). Identifying factors that affecting the entrepreneurial intention among engineering technology students. Procedia-Social and Behavioral Sciences, 211, 1016-1022. https://doi.org/10.1016/j.sbspro.2015.1 1.135

Mintardjo, C. M. O., Ogi, I. W., Kawung, G. M. V, Raintung, M. C., \& Ratulangi, U. S. (2020). Sejarah Teori Kewirausahaan: Dari Saudagar Sampai Ke Teknoprenur Startup. Jurnal Ilmiah
Manajemen Bisnis Dan Inovasi,7(2), 187-196.

Mopangga, H. (2014). Faktor Determinan Minat Wirausaha Mahasiswa Ekonomi dan Bisnis Universitas Negeri Gorontalo. Jurnal Ekonomi Trikonomika, 13(9), 78-90.

Munawar, A., \& Supriatna, N. (2018). Pengaruh Sikap dan Motivasi Terhadap Minat Berwirausaha Siswa. OIKOS: Jurnal Kajian Pendidikan Ekonomi Dan Ilmu Ekonomi, 2(1), 14-23. https://doi.org/10.23969/oikos.v2i1.91 6

Nadya, L., \& dkk. (2019). Pengaruh Efikasi Diri, Motivasi Berwirausaha, Kreativitas, dan Lingkungan Keluarga terhadap Minat Berwirausaha Siswa Kelas XII Smk Patria Gadingrejo Tahun Pelajaran 2018/2019. JEE (Jurnal Edukasi Ekobis), 6(1), 1-14. https://garuda.ristekbrin.go.id/documen ts/detail/903768

Neneh, B. N. (2014). An assessment of entrepreneurial intention among university students in cameroon. Mediterranean Journal of Social Sciences, 5(20), 542-552. https://doi.org/10.5901/mjss.2014.v5n2 0p542

Ningsih, S., \& Dukalang, H. H. (2019). Penerapan Metode Suksesif Interval pada Analsis Regresi Linier Berganda. Jambura Journal of Mathematics, 1(1), 43-53.

https://doi.org/10.34312/jjom.v1i1.174 2

Noviasari, D. Haryono, Andi Tri., \& Fathoni, Azis. (2018). Analisis Pengaruh Kualitas Pembelajaran Kewirausahaan, Kreativitas Inovasi, dan Modal Sosial Terhadap Minat Wirausaha Dengan Efikasi Diri Sebagai Variabel Intervening (Studi Pada Siswa SMKN 3 Semarang). Journal of Management: Jurnal Ilmiah Mahasiswa, 4(4), 1-21

Nurmaliza, N., Caska, C., \& Indrawati, H. (2018). Analysis of factors affecting entrepreneurial interest of vocational high school students in Pekanbaru. 
Journal of Educational Sciences, 2(2), 42-51.

https://doi.org/10.31258/jes.2.2.p.4251

Osakede, U. A., Lawanson, A. O., \& Sobowale, D. A. (2017). Entrepreneurial Interest and academic performance in Nigeria: evidence from undergraduate students in the university of Ibadan. Journal of Innovation And Entrepreneurship, 6(1). https://doi.org/10.1186/s13731017-0079-7

Prakoso, Albrian Fiky., Kurniawan, Riza Yonisa., \& Soesatyo, Yoyok. (2019). Students Entrepreneurship Intention in Metropolitan and Indonesia Free Trade Zone: Is it Different?. Information Management and Business Review, 11(4), 1-12.

Praswati, A. N. (2014). Analisis FaktorFaktor yang Mempengaruhi Minat Wirausaha di Kalangan Mahasiswa Studi Kasus: Fakultas Ekonomi dan Bisnis Universitas Muhammadiyah Surakarta. Seminar Nasional Dan Call for Paper (Sancall 2014), Sancall, 134-142.

https://publikasiilmiah.ums.ac.id/xmlui /handle/11617/4647

Priyatna, S. E. (2020). Analisis Statistik Sosial Rangkaian Penelitian Kuantitatif Menggunakan SPSS. Yayasan Kita Menulis.

Putri, K., Pradhanawati, A., \& Prabawani, B. (2014). Pengaruh Karakteristik Kewirausahaan, Modal Usaha dan Peran Business Development Service Terhadap Pengembangan Usaha (Studi Pada Sentra Industri Kerupuk Desa Kedungrejo Sidoarjo Jawa Timur). Jurnal Ilmu Administrasi Bisnis S1 Undip, 3(4), 313-322.

Rahayu, E. S., \& Laela, S. (2018). Pengaruh Minat Berwirausaha dan Penggunaan Sosial Media terhadap Kewirausahaan Mahasiswa. Jurnal Pengembangan Wiraswasta, 20(3), 203-216. https://doi.org/10.33370/jpw.v20i3.246
Rahmadi, Nur Afif, \& Heryanto, B. (2016). Analisis Faktor-Faktor yang Mempengaruhi Minat Berwirausaha Pada Mahasiswa Program Studi Manajemen Fakultas Ekonomi Universitas Kadiri. Jurnal Ekonomi Universitas Kadiri, 1,(2), 153-169.

Ranto, Dwi Wahyu P. (2016). Membangun Perilaku Entrepenuer. Jurnal Bisnis Manajemen dan Akuntansi, III(1), 7986.

Rifkhan. (2017). Pengaruh Sikap dan Motivasi terhadap Minat Berwirausaha Mahasiswa Akuntasi Universitas Pamulang. Jurnal Ilmiah Akuntansi Universitas Pamulang, 5(1), 121-154. http://openjournal.unpam.ac.id/index.p $\mathrm{hp} / \mathrm{JIA} /$ article/view/645

Rosadi, E. (2019). Pengaruh Modal dan Tenaga Kerja Terhadap Pendapatan Bersih Perusahaan dalam Perspektif Ekonomi Islam (Studi pada Home Industri Krupuk Kemplang Skip Rahau Kec. Bumi Waras Teluk Betung Kota Bandar Lampung). Thesis. Universitas Islam Negeri Raden Intan Lampung

Roscoe. (1982). Research Methods For Business. New York: Mc Graw Hill.

Rosmiati, R., Junias, D. T. S., \& Munawar, M. (2015). Sikap, Motivasi, dan Minat Berwirausaha Mahasiswa. Jurnal Manajemen Dan Kewirausahaan, Journal of Management and Entrepreneurship, 17(1), 21-30. https://doi.org/10.9744/jmk.17.1.21-30 Sihombing, I. K., \& Sumantri, B. (2014). Analisis Motivasi Mahasiswa Dalam Berwirausaha Pada Politeknik LP3I Medan. Jurnal Bisnis Administrasi, 03(2), 56-66.

Sugiyono. (2016). Metode Penelitian Pendidikan (Pendekatan Kuantitatif, Kualitatif, dan $R \& D)$. Bandung: CV Alfabeta.

Suryana. (2003). Kewirausahaan (Edisi Revisi). Jakarta: Salemba Empat.

Tanusi, G., \& Laga, Y. (2020). Pengaruh Pelatihan, Motivasi dan Modal Usaha terhadap Minat Berwirausaha Di 
UPTD IIK UKM Kabupaten Ende. KINERJA, 17(1), 157-163.

Widarwati, T. (2015). Pengaruh Prestasi

Belajar Prakarya Kewirausahaan,

Business Center dan Praktik Kerja

Industri Terhadap Minat

Berwirausaha Siswa Kelas XI Paket

Keahlian Akuntansi SMK Negeri 1

Boyolali Tahun Ajaran 2014/2015.

123Dok. https://text-

id.123dok.com/document/1y9n9ojdz-

koefisien-determinasi-simultan-r-

koefisien-determinasi-secara-parsial-

r.html.

Wijayangka, C., \& dkk. (2018). Pengaruh

Motivasi Terhadap Minat

Berwirausaha Mahasiswa Program

Studi Administrasi Bisnis Universitas

Telkom. ECo-Buss, 1(4), 55-61.

Wulandari, V. S. (2016). Hubungan Sikap Kepribadian, Kretivitas, dan Inovasi Terhadap Sikap Minat Berwirausaha Mahasiswa. Skripsi. Universitas Sanata Dharma https://search.proquest.com/docview/1 443861513 ?accountid=26646\%0Ahttp: //link.periodicos.capes.gov.br/sfxlc141? url_ver=Z39.88-

2004\&rft_val_fmt=info:ofi/fmt:kev:mt $\mathrm{x}$ :dissertation \& genre $=$ dissertations $+\% 2$ 6+theses\&sid=ProQ:ProQuest+Dissert ations+\%26+Theses+Globa.

Yulianeu, \& Harini, C. (2018). Faktor-Faktor yang Mempengaruhi Minat Berwirausaha. Jipis, 25(2), 1-21. 